Appl. Radiat. Isot. Vol. 42, No. 3, pp. 309-311, 1991 Int. J. Radiat. Appl. Instrum. Part A

C Pergamon Press plc 1991. Printed in Great Britain $0883-2889 / 91 \$ 3.00+0.00$

\section{A Rapid High Yield Synthesis of No-Carrier-Added (-)-[123|Iodocyanopindolol*}

\author{
MARCIAN E. VAN DORT, $\uparrow$ \\ DAVID L. GILDERSLEEVE and \\ DONALD M. WIELAND
}

Division of Nuclear Medicine, University of Michigan Medical School, Ann Arbor, MI 48109-0552, U.S.A.

\section{(Received 4 September 1990)}

A convenient and efficient radiosynthesis of no-carrier-added $\left[{ }^{123} \mathrm{I}\right]$ labeled (-)iodocyanopindolol, $\left.(-)-\left[{ }^{123}\right\}\right][C Y P$, a high affinity $\beta$ adrenergic antagonist, is described. $\left.(-)-\left[{ }^{123}\right]\right] I C Y P$ was synthesized by a modified chloramine- $T$ radioiodination of (-)cyanopindolol followed by a novel reversed-phase HPLC purification that provided the radiopharmaceutical as a directly injectable solution. The total synthesis time was typically less than $45 \mathrm{~min}$ and provided $\left.(-)-\mathrm{I}^{123} \mathrm{I}\right] \mathrm{ICYP}$ in a $59 \%$ radiochemical yield (not corrected for decay). In view of its high affinity for the $\beta$ adrenergic receptor, $\left.(-)-\left[{ }^{123}\right]\right] I C Y P$ is a potentially useful probe for SPECT evaluation of cardiac adrenergic receptor densily.

\section{Introduction}

The $\beta$ adrenergic receptor has been the subject of intensive study in the past two decades. Rapid progress in the adrenergic receptor field has been in part due to the availability of a variety of high affinity radiolabeled probes (Molinoff, 1984). (-)-[125I]Iodocyanopindolol, (-)-[125I]ICYP, which is commercially available at the theoretically maximum specific activity of $2175 \mathrm{Ci} \mathrm{mmol}^{-1}$ is one such radioligand widely used for in vitro studies of the $\beta$ adrenergic receptor (Engel et al., 1981; Hoyer et al., 1982). ICYP (Fig. 1) displays high in vitro affinity $\left(K_{\mathrm{D}}=40 \mathrm{pM}\right)$ for the $\beta$ adrenergic receptor while displaying low affinity for $\alpha$ adrenergic and serotonin receptors (Engel et al., 1981); however, ICYP does not discriminate between the $\beta_{1}$ and $\beta_{2}$ adrenergic subtypes (Lands et al., 1966, 1967). Recently Brodde and coworkers utilizing $(-)-\left[{ }^{125} I\right] I C Y P$ demonstrated the coexistence of $\beta_{1}$ and $\beta_{2}$ adrenergic receptors as well as a predominance of the $\beta_{1}$ subtype in human right atria (Brodde $e t$ al., 1983). Despite this development by Brodde and others (Stiles $e t$ al., 1983), the functional role of the $\beta_{2}$ adrenergic subtype in human heart remains unknown at the present time (Brodde et al, 1983, 1987).

The high affinity and selectivity of ICYP for $\beta$ adrenergic receptors makes ${ }^{123} \mathrm{I}$ labeled ICYP an ideal candidate for the in vivo mapping of cardiac $\beta$ adrenergic receptors. Moreover, the general availability of single photon tomographic (SPECT) instruments in nuclear medicine clinics and the improved resolution of these modern SPECT scanners have given impetus to the development of ${ }^{123}$ I-labeled tracers for

*Presented in part at the Society of Nuclear Medicine Meeting, July 1989. J. Nucl. Med. 30, 859, abstr. 544. tAuthor for correspondence.

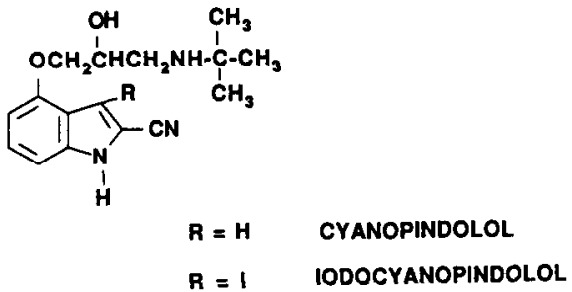

Fig. 1

in vivo receptor mapping (Ter-Pogossian, 1985). We report here a simple and rapid method for the routine preparation of millicurie amounts of no-carrier-added $\left.(-)-\left[{ }^{223}\right]\right] I C Y P$ for use in in vivo mapping studies of the $\beta$ adrenergic receptor system.

\section{Materials and Methods}

$(-)$ Cyanopindolol and $( \pm)$ cyanopindolol were obtained as generous gifts from Sandoz Ltd, Basel, Switzerland. $\mathrm{Na}\left[{ }^{125}\right.$ I]jodide was obtained from DuPont New England Nuclear, Boston, $\mathrm{MA}$ as a no-carrier-added solution in $0.1 \mathrm{M} \mathrm{NaOH},(\mathrm{pH}=10-12) . \mathrm{Na}\left[{ }^{123}\right]$ liodide was obtained from Nordion Ltd, Ontario. Canada as a no-carrier-added solution in $0.1 \mathrm{M} \mathrm{NaOH}(\mathrm{pH}=10$ 12). Reagent grade water was from a Milli-Q⿱乛龰 system (Millipore Corp., Bradford, MA). HPLC grade acetonitrile was from Mallinckrodt Inc., Paris, KY, and $95 \%$ ethanol was from Aaper Alcohol and Chemical Co., Shelbyville, KY. All other reagents were of analytical grade and obtained from Aldrich Chemical Co., Milwaukee, WI

Radioactivity was assayed with a Capintec radioisotope calibrator model CRC-12R. Solvent removal from the radioactive solutions was achieved with a Wheaton Model VV micro-rotoevaporator. The entire procedure involving synthesis, workup and HPLC purification was conducted behind lead shielding in a well ventilated hood dedicated to radiochemical syntheses.

\section{Thin layer chromatography}

Thin layer chromatography of the radiolabeled products (radio-TLC) was performed utilizing the following systems.

(1) System I: ammonium formate, $0.1 \mathrm{M}$ with $0.01 \%$ phenol, $\mathrm{pH} 8.5,20 \mathrm{~cm}$ cellulose glass backed plates $(250 \mu \mathrm{m}$, Whatman $\mathrm{K} 2 \mathrm{~F}) ; R_{f}$ of ICYP $=0.09 ; R_{f}$ of $\mathrm{CYP}=0.54$

(2) System II: $\mathrm{CH}_{3} \mathrm{OH}: \mathrm{H}_{2} \mathrm{O}: \mathrm{HOAc}(80: 20: 0.15), 20 \mathrm{~cm}$ reversed-phase $\mathrm{C}-18$ glass backed plates $(250 \mu \mathrm{m}$, Whatman $\mathrm{KC} 18 \mathrm{~F}) ; R_{f}$ of ICYP $=0.53, R_{f}$ of $\mathrm{CYP}=0.65$.

(3) System III: EtOH:EtOAc $(1: 1) ; 20 \mathrm{~cm}$ silica gel glass backed plates $\left(250 \mu \mathrm{m}\right.$, Whatman K6F); $R_{f}$ of ICYP $=0.09 ; \quad R_{f}$ of $\mathrm{CYP}=0.09 ; R_{f}$ of $\mathrm{Na}\left[{ }^{125}\right.$ I] $]$ iodide $=0.71$.

The radioactive solutions were spotted over their respective nonradioactive standards prior to elution. The plates were analyzed on a Berthold Model LB2832 TLC-Linear Analyzer equipped with a Model LB500 Data Acquisition System.

\section{HPLC and radio-HPLC analyses}

Analysis and purification of $\left.(-)-{ }^{125} \mathrm{I}\right] \mathrm{ICY}$. was performed with a Beckman Model 110B pump equipped with a Rheodyne Model 7010 injection valve and an Ultrasphere ODS ${ }^{\mathrm{TM}}$ column $(4.6 \times 45 \mathrm{~mm}, 5-\mu \mathrm{m}$ particle, Beckman Instruments, Berkeley, CA). Radioactivity was monitored with a Beckman 170 radioactivity detector. The HPLC elution solvent 
consisted of $25 \mathrm{mM}$ acetic acid in $30 \%$ ethanol: $\mathrm{H}_{2} \mathrm{O}$ at a flow rate of $2.0 \mathrm{~mL} \mathrm{~min}-1$.

Analytical HPLC of unlabeled $( \pm$ )ICYP was performed with a Beckman Model 112 pump and an Ultrasphere ODS $^{\mathrm{TM}}$ column $(4.6 \times 250 \mathrm{~mm}, 5-\mu \mathrm{m}$ particle, Beckman Instruments, Berkeley, $\mathrm{CA})$ with $\mathrm{CH}_{3} \mathrm{CN}: 0.1 \mathrm{M}\left(\mathrm{NH}_{4}\right)_{2} \mathrm{CO}$ (1:1). Column efluent was monitored at $254 \mathrm{~nm}$ with a Kratos Spectroflow 773 u.v. absorbance detector. At a flow rate of $1.0 \mathrm{~mL} \mathrm{~min}^{-1} \mathrm{CYP}$ and ICYP were completely resolved with retention times of 12.2 and $21 \mathrm{~min}$, respectively. Preparative reversed-phase HPLC purification of unlabeled $( \pm$ )ICYP was performed with a Beckman Model 110B pump equipped with a Rheodyne Model 7010 injection valve and a Phenomenex Ultremex C-18 IP column $(10 \times 250 \mathrm{~mm}, 5-\mu \mathrm{m}$ particle). Absorbance was monitored at $254 \mathrm{~nm}$ by means of an ISCO UA-5 absorbance detector equipped with an ISCO Type 9 Optical unit. The elution solvent was $\mathrm{CH}_{3} \mathrm{CN}: 0.1 \mathrm{M}$ $\left(\mathrm{NH}_{4}\right)_{2} \mathrm{CO}_{3}(1: 1)$ at a flow rate of $5.0 \mathrm{~mL} \mathrm{~min}{ }^{-1}$.

Analytical chiral HPLC of ICYP was performed on a Chiracel OD column $(4.6 \times 250 \mathrm{~mm}, 10-\mu \mathrm{m}$ particle, Daicel Chemical Industries Ltd) with hexane: isopropanol: diethylamine $(50: 50: 0.1)$ at a flow rate of $0.5 \mathrm{~mL} \mathrm{~min}^{-1}$. Under these conditions the retention times of the $(+)$ and $(-)$ isomers of ICYP were 9.2 and $10.7 \mathrm{~min}$, respectively.

\section{Synthesis of (-)-I'P3IICYP}

The radiosynthesis of $(-)-{ }^{[23}$ I]ICYP was carried out by slight modification of the procedure (Engel et al., 1981) described for the synthesis of [ ${ }^{i 25}$ I]ICYP and is typically as follows. To a polypropylene tube $(12 \times 75 \mathrm{~mm}$, Sarstedt, F.R.G.) was added in sequential order $(-)$ CYP $(20 \mu \mathrm{g}$ in $10 \mu \mathrm{L}$ of $13.5 \mathrm{mIM} \mathrm{HCl}$ ), $0.3 \mathrm{M}$ polassium phosphate buffer $(85 \mu \mathrm{L}, \mathrm{pH}=6.75)$ and aqueous $\mathrm{NA}\left[{ }^{123} \mathrm{I}\right]$ iodide $(27 \mathrm{mCi}$ in $85 \mu \mathrm{L}$ of $0.1 \mathrm{M} \mathrm{NaOH}$ ). The reaction was initiated by the addition of aqueous Chloroamine-T $\left(20 \mu \mathrm{L} ; 0.34 \mathrm{mg} \mathrm{mL}^{-1}\right)$, and the reaction tube capped. After standing for $5 \mathrm{~min}$ at room temperature, the reaction was quenched with aqueous $\mathrm{Na}_{2} \mathrm{~S}_{2} \mathrm{O}_{3}\left(300 \mu \mathrm{L}, 1 \mathrm{mg} \mathrm{mL}{ }^{-1}\right)$ followed by aqueous $1 \mathrm{M}$ $\mathrm{NaOH}(180 \mu \mathrm{L})$. The aqueous solution was extracted with EtOAc containing $0.01 \%$ phenol $(3 \times 1 \mathrm{~mL})$. Vortexing was performed during each extraction procedure to facilitate mixing and separation of the layers and the organic layer was removed by means of a pasteur pipette. The EtOAc layer (containing $22 \mathrm{mCi}$ of product) was transferred to a $10 \mathrm{~mL}$ screw-capped glass V-vial and an aliquot was removed for radio-TLC analysis (TLC Systems I and III). Removal of solvent was accomplished at $40^{\circ} \mathrm{C}$ using a miniature rotary evaporator fitted with a dry ice/isopropanol condenser connected to a vacuum pump. The residue was reconstituted in $0.5 \mathrm{~mL}$ of $25 \mathrm{mM}$ acetic acid in EtOH: $\mathrm{H}_{2} \mathrm{O}$ (1:9) for purification by HPLC as described. CYP and (-)$\left[{ }^{123} \mathrm{I}\right] \mathrm{ICYP}$ were completely resolved with retention times of 4.1 and $11.2 \mathrm{~min}$ respectively. The isolated product $(16 \mathrm{mCi}$; $59 \%$ radiochemical yield uncorrected for decay) was collected in an $8 \mathrm{~mL}$ fraction

\section{Synthesis of $( \pm)-\left[^{127} I\right] I C Y P$}

This was carried out by modification of the procedure reported by Bearer and coworkers for the synthesis of iodohydroxybenzylpindolol (Bearer ct al., 1980). A stirred clear solution of ( \pm CYP $\left(10 \mathrm{mg}, 3.5 \times 10^{-2} \mathrm{mmol}\right)$ in $70 \mathrm{mM}$ $\mathrm{HCl}(1.0 \mathrm{~mL})$ was treated with $0.3 \mathrm{M}$ potassium phosphate buffer $(2.0 \mathrm{~mL}, \mathrm{pH}=6.8)$ followed by solid $\mathrm{Na}^{127} \mathrm{~T}(5.2 \mathrm{mg}$, $\left.3.5 \times 10^{-2} \mathrm{mmol}\right)$. The above solution was treated dropwise with stirring at $5 \mathrm{C}$ (ice-water bath) with a freshly prepared solution of Chloramine- $\mathrm{T}\left(10 \mathrm{mg}, 3.5 \times 10^{-2} \mathrm{mmol}\right.$ ) in $\mathrm{H}_{2} \mathrm{O}$ $(1.0 \mathrm{~mL})$ over a period of $30 \mathrm{~min}$. The reaction was then warmed to room temperature and stirred an additional $2 \mathrm{~h}$ until completion (progress of the reaction was monitored by analytical HPLC). The reaction was terminated by quenching with solid $\mathrm{Na}_{2} \mathrm{~S}_{2} \mathrm{O}_{3}(16 \mathrm{mg})$ and the $\mathrm{pH}$ of the mixture was adjusted to 10 by the addition of solid $\mathrm{NaOH}(40 \mathrm{mg})$. The aqueous solution was extracted with EtOAc $(3 \times 25 \mathrm{~mL})$ and the combined organic layers were washed with $\mathrm{H}_{2} \mathrm{O}$ $(1 \times 25 \mathrm{~mL})$ and dried $\left(\mathrm{Na}_{2} \mathrm{SO}_{4}\right)$. Removal of volatiles afforded $19 \mathrm{mg}$ of a clear oil which was further purified by preparative reversed-phase HPLC as described in the Materials and Methods section. The fraction containing the desired product was extracted with EtOAc $(3 \times 75 \mathrm{~mL})$, washed with $\mathrm{H}_{2} \mathrm{O}(1 \times 25 \mathrm{~mL})$, dried $\left(\mathrm{Na}_{2} \mathrm{SO}_{4}\right)$ and concentrated to afford $9 \mathrm{mg}(62 \%)$ pure $( \pm)-\left.\right|^{127} \mathrm{I} I \mathrm{ICYP} .360 \mathrm{MHZ}$ ${ }^{1} \mathrm{H}$ NMR ( $\mathrm{d}_{6}$ acetone) confirmed that the location of the iodine atom is at the 3-position of the indole nucleus by the absence of the 3 -indole proton singlet at $7.35 \mathrm{ppm}$ found in the spectrum of CYP.

\section{Results and Discussion}

The clinical potential of $(-)-\left[{ }^{123} I\right] I C Y P$ as a SPECT agent for in vivo mapping of $\beta$ adrenergic receptors has prompted us to develop a convenient, reliable and efficient synthesis of this radiotracer. Previous methods for the synthesis of carrierfree $\left[{ }^{125} \mathrm{I}\right] \mathrm{ICYP}$ required a 4 -h purification by descending paper chromatography and are clearly unsuitable for routine production of the shorter lived [ $\left.{ }^{123} \mathrm{I}\right]$ analog $\left(T_{1: 2}\right.$ of ${ }^{123} \mathrm{I}$ $=13.5 \mathrm{~h})$. The synthesis described here is a quick and reproducible method.

Since unlabeled $( \pm$ ICYP was needed as an analytical standard for the HPLC analyses and synthetic details were unavailable in the original literature (Engel et al., 1981), this compound was synthesized by us as described. Initial optimization of the labeling conditions was carried out with $\mathrm{Na}\left[{ }^{125} \mathrm{I}\right]$ iodide due to its ease of handling and longer half-life $\left(T_{1,2}=60\right.$ days $)$.

The radiolabeling of CYP with $\left[{ }^{123}\right.$ Ijiodide was patterned after the previously described method for the synthesis of the ${ }^{125} 1$ ligand (Engel ef al., 1981). A notable difference was that the ${ }^{123}$ I labeling reaction was usually conducted at a 3-fold greater dilution since commercially available $\mathrm{Na}\left[{ }^{123} \mathrm{I}\right]$ iodide is present in a larger volume of $0.1 \mathrm{M} \mathrm{NaOH}$ $(85-\mathrm{l} 10 \mu \mathrm{L})$. This necessitated the use of a larger volume of phosphate buffer in order to maintain a $\mathrm{pH}$ close to neutrality since labeling yields are known to dramatically decline at high pH (Petzold and Coenen, 1981; Wilson et al., 1989). Despite this modification, high yields of [1231]ICYP were obtained in 5 min. Extraction of the $\left[{ }^{123} \mathrm{I}\right] \mathrm{ICY}$ into EtOAc from the basic aqueous solution is virtually quantitative; this step also removes much of the unreacted $\left[{ }^{123} \mathrm{I}\right]$ iodide. RadioTLC analysis (System III) indicates the presence of less than $3 \%$ unreacted $\left.\left[{ }^{123}\right]\right]$ iodide in the organic phase. Removal of the EtOAc by means of a microrotoevaporator was generally complete in less than $3 \mathrm{~min}$. Separation of $\left[{ }^{123} \mathrm{I}\right] \mathrm{ICY}$ from CYP was readily achieved by reversed-phase HPLC. Under the conditions described, CYP elutes as a single sharp peak (retention time $=4.1 \mathrm{~min}$ ) and the more lipophillic ICYP elutes later (retention time $=11.2 \mathrm{~min}$ ). Any residual unreacted $\left[{ }^{123} I\right]$ iodide elutes with the solvent front. In all cases the labeled product displayed HPLC elution profiles identical to unlabeled ICYP. The use of EtOH: $\mathrm{H}_{2} \mathrm{O}: \mathrm{HOAc}$ as the HPLC solvent eliminated the need to remove solvent and provided the radiotracer as a directly injectable solution requiring only filtration.

Specific activity of $\left[{ }^{125} 1\right]$ ICYP was estimated as greater than $1550 \mathrm{Ci} \mathrm{mmol}^{-1}$ from a standard curve relating mass to u.v. absorbance peak area. Since $(-)-\left[^{123} I\right] I C Y P$ was synthesized using conditions identical to that of [ $\left.{ }^{125} I\right]$ ICYP. its specific activity would therefore be correspondingly higher depending on the actual specific activity of the $\left[{ }^{123} \mathrm{I}\right]$ iodide used.

Chiral HPLC comparison of (-)- $\left[^{[25}[]\right.$ ICYP with an enantiomeric mixture obtained by $\left[{ }^{125} I\right]$ iodide labeling of $( \pm$ CYP showed no evidence of racemization during the radioiodination step.

In conclusion, the method described here is simple, rapid and efficient and makes available millicurie amounts of no-carrier-added $(-)-\left[{ }^{123}\right.$ I]ICYP for in vivo studies. Efforts 
are underway to automate the radiosynthetic procedure to minimize radiation exposure, particularly at the extractive workup stage.

Acknowledgements - We are indebted to Dr James Sisson for his interest in ICYP that led to the initiation of this project. We thank the Phoenix Memorial Laboratory at the University of Michigan for the use of their facilities and Linder Markham for typing the manuscript. This work was supported by the National Institutes of Health Grant No. HL27555.

\section{References}

Bearer C. F., Knapp R. D., Kaumann A. J., Swartz T. L. and Birnbaumer L. (1980) Iodohydroxybenzylpindolol: preparation, purification, localization of its iodine to the indole ring, and characterization as a partial agonist. Molec. Pharmac. 17, 328.

Brodde O. E., Karad K., Zerkowski H. R., Rohm N. and Reidemeister J. C. (1983) Coexistence of $\beta_{1}{ }^{-}$and $\beta_{3}$ adrenoceptors in human right atrium: direct identification by $( \pm)\left[{ }^{125}[]\right.$ iodocyanopindolol binding. Circ. Res. 53, 752.

Brodde O. E., Beckeringh J. J. and Michel M. C. (1987) Human heart $\beta$-adrenoceptors: a fair comparison with lymphocyte $\beta$-adrenoceptors? Trends Pharmac. Sci. 8, 403.

Engel G., Hoyer D., Berthold R. and Wagner H. (1981) $( \pm)\left[{ }^{125}\right.$ Iodo]cyanopindolol, a new ligand for $\beta$-adrenoceptors: identification and quantitation of subclasses of $\beta$-adrenoceptors in guinea pig. Naunyn-Schmiedeberg's Arch. Pharmac. 317, 277.

Hoyer D., Engel G. and Berthold R. (1982) Binding characteristics of $(+)-,( \pm)-$ and $(-)-\left.\right|^{125}$ iodo]cyanopindolol to guinea-pig left ventricle membranes. Naunyn-Schmiedeberg's Arch. Pharmac. 318, 319.

Lands A. M., Groblewski G. E. and Brown T. G. (1966) Comparison of the action of isoproterenol and several related compounds on blood pressure, heart and bronchioles. Arch. Int. Pharmacodyn. 161, 68.

Lands A. M., Arnold A., McAuliff J. P., Luduena F. P. and Brown T. G. (1967) Differentiation of receptor systems activated by sympathomimetic amines. Nature, Lond. 214, 597.

Molinoff P. B. (1984) $\alpha$ - and $\beta$-Adrenergic receptor subtypes: properties, distribution and regulation. Drugs 28 (Suppl. 2), 1.

Petzold G. and Coenen H. H. (1981) Chloramine-T for "no-carrier-added" labeling of aromatic biomolecules with Bromine-75, 77. J. Labelled Comp. Radiopharmac. 18, 1319.

Stiles G. L., Taylor S. and Lefkowitz R. J. (1983) Human cardiac beta-adrenergic receptors: subtype heterogeneity delineated by direct radioligand binding. Life Sci. 33, 467.

Ter-Pogossian M. M. (1985) PET, SPECT and NMRI: competing or complementary disciplines? J. Nucl. Med. 26, 1487.

Wilson A. A., Grigoriadis D. E., Dannals R. F., Ravert H. T. and Wagner H. N. Jr (1989) A one-pot radiosynthesis of ['25] I]iodoazido photoaffinity labels. J. Labelled Comp. Radiopharmac. 27, 1299. 